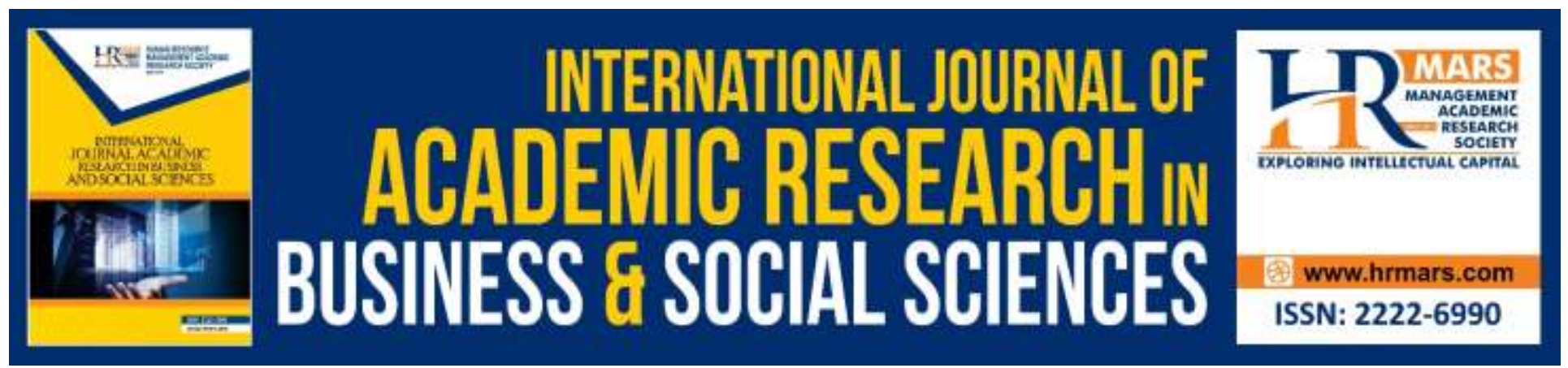

\title{
The Barriers and Obstacles of Attitude towards Online Shopping in the Malaysian Market
}

Roszi Naszariah Nasni Naseri, Norfaridatul Akmaliah Othman, Nik Rahila Wan Ibrahim

To Link this Article: http://dx.doi.org/10.6007/IJARBSS/v10-i6/7314

DOI:10.6007/IJARBSS/v10-i6/7314

Received: 19 March 2020, Revised: 27 April 2020, Accepted: 04 May 2020

Published Online: 25 June 2020

In-Text Citation: (Naseri et al., 2020)

To Cite this Article: Naseri, R. N. N., Othman, N. A., \& Ibrahim, N. R. W. (2020). The Barriers and Obstacles of Attitude towards Online Shopping in the Malaysian Market. International Journal of Academic Research in Business and Social Sciences, 10(6), 440-448.

Copyright: (c) 2020 The Author(s)

Published by Human Resource Management Academic Research Society (www.hrmars.com)

This article is published under the Creative Commons Attribution (CC BY 4.0) license. Anyone may reproduce, distribute, translate and create derivative works of this article (for both commercial and non-commercial purposes), subject to full attribution to the original publication and authors. The full terms of this license may be seen at: $\underline{\text { http://creativecommons.org/licences/by/4.0/legalcode }}$

Vol. 10, No. 6, 2020, Pg. 440 - 448

http://hrmars.com/index.php/pages/detail/IJARBSS

JOURNAL HOMEPAGE

Full Terms \& Conditions of access and use can be found at http://hrmars.com/index.php/pages/detail/publication-ethics 


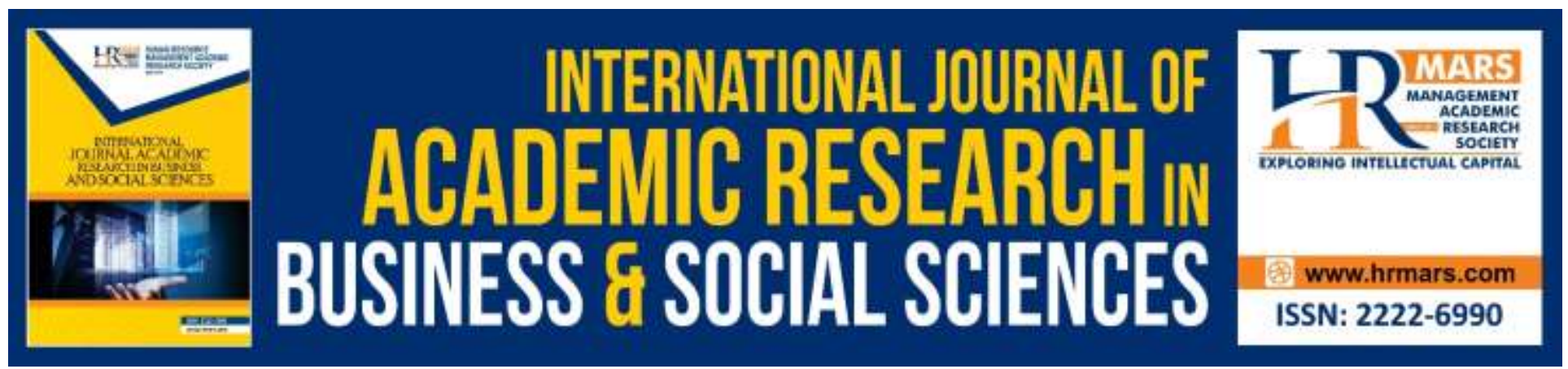

\title{
The Barriers and Obstacles of Attitude towards Online Shopping in the Malaysian Market
}

\author{
Roszi Naszariah Nasni Naseri \\ Faculty of Technology Management \& Technopreneurship, Universiti Teknikal Malaysia Melaka \\ and Universiti Teknologi MARA Melaka. \\ Email: roszinasni@gmail.com
}

Norfaridatul Akmaliah Othman

Faculty of Technology Management \& Technopreneurship Universiti Teknikal Malaysia Melaka

\section{Nik Rahila Wan Ibrahim}

Centre for Languages and Human Development Universiti Teknikal Malaysia Melaka

\begin{abstract}
This review paper focuses on the barriers and obstacle of attitude towards online shopping in the Malaysian market. From the review of literature, it is found that the Malaysian online shopping is still at the beginning stage as compared to other Asian countries which are at a more advanced stage. Among the contributor to this issue is the lack of understanding and negative attitude towards online shopping. Due to that, four main barriers have been identified and they are: privacy and security, trust, web design and perceived ease of use. This study is still at the early stage and needs further validation by reputable scholars and experts in the field to enhance its credibility. Thus, the issue will be explored further through quantitative study.
\end{abstract}

Keywords: Barriers, Obstacles, Online Shopping, Attitude, Malaysia, Market.

\section{Introduction}

A Consumer's attitude towards online shopping refers to the psychological state in which she or he is in, while making purchases over the Internet. Attitude directly influences decision making and is also central to a buyer's shopping behaviour. Therefore, the group with a more positive attitude should be the target market (Wu, 2003).

Faqih (2016) and Salem ur Rahman (2018) also noted that the characteristics and features of this new shopping method are still unfamiliar to consumers in developing countries and therefore needs more attention. It is no surprise then, that Haque et al (2006) observed thatthe attitude towards online shopping is somewhat negative among Malaysians This is because of the lack of understanding about online shopping and the impact on marketing (Harn, Khatibi \& Ismail, 2006) and the less known facts about what determines online shopping and consuming attitude (Muniandy, Al- 
INTERNATIONAL JOURNAL OF ACADEMIC RESEARCH IN BUSINESS AND SOCIAL SCIENCES Vol. 10, No. 6, June, 2020, E-ISSN: 2222-6990 @ 2020 HRMARS

Mamun, Permarupan \& Zainol, 2014). It is supported by the study by Harn, Khatibi and Ismail (2006); Haque et al. (2009); Lim et al. (2016) mentioned that online shopping in Malaysia is still evolving and unfamiliar. This is further proven by the study by Jamil and Mat (2011) who stated that only a few studies were conducted on online shopping attitude of consumers in Malaysia. Online shopping in Malaysia is still at an early stage and little is known about consumer attitude toward this new channel of shopping and factors that influence their attitude towards it.

This statement was supported by the Malaysian Communications and Multimedia Commission (MCMC) which conducted the Internet Users Survey (IUS) 2017 and found that there is a $66.7 \%$ lack of confidence or skills and $64.6 \%$ security and privacy concerns as being the main reason for not shopping online. Figure 1 shows the list of reason for not shopping online.

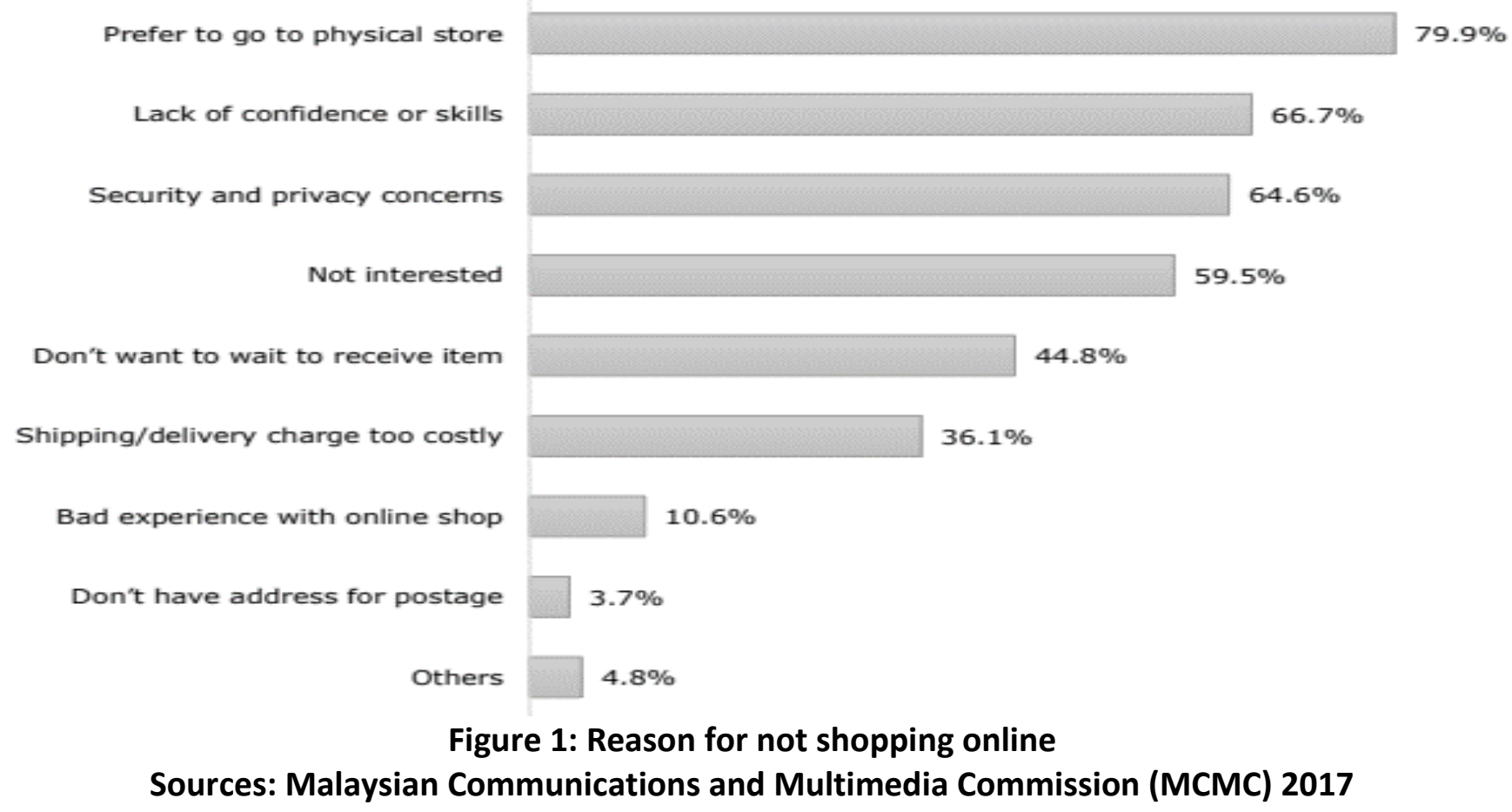

In order to increase online shopping in Malaysia, factors influencing consumer attitude when shopping online should be given priority. It is important to identify the factors which influence consumers to shop online in order to capture the demands of consumers. It is important to address factors that could influence shopping behaviours (Azeem, 2012). Ignoring consumers' attitudes guarantees limited success of a marketing strategy campaign (Bhatt, 2014). Most of the previous studies has used variables such as belief (Oh and Jeong, 2015), brand (Kudeshia \& Kumar, 2017; Punyatoya, 2015; Park et al. 2015) consumer experience (Yeo, Goh \& Rezaei, 2017), knowledge (Wulandri, Rahyuda \& Yasa, 2015) as the factors that influence consumer attitude towards purchase intention. With this in mind the objective of this study is:

- to review the factors such as trust, privacy and security, perceived ease of use and web design as the reasons that influence consumer attitude toward online purchase intention. 


\section{Overview of Barriers and Obstacle}

According to Ranganathan \& Ganapathy (2002) privacy and security are the best predictors of consumer attitude toward online purchase intention. Security risk is the main issue (figure 2) which takes up 74 per cent (Nielsen Global Survey, 2016) of what consumers are worried the most when they engage in an online purchase (Bart et al. 2005). It is supported by the study done by Levy and Weitz (2016) which reveals that security and privacy violations are the most important factors that hinder consumers from buying through online shopping. Malaysian people are unwilling to shop online because they are afraid their personal information will be stolen or misused by others (Haque et al. 2006). Tong (2010) indicates that a higher perception of risk leads to a fewer willingness to buy. The Malaysian Insider (2011) reported that four (4) out of ten (10) Malaysian online shoppers believe that security measures on credit/debit card online transactions online (Zendehdel et al. 2015) were inadequate. Egger (2000) noted that difficulty of use with respect to online payment privacy found to constitute a real barrier to online shopping. Consequently, the study by Belkhamza \& Niasin (2017) mentioned that there is lack of research on the privacy concern on consumer attitude toward purchase intention. When the privacy and security is secure, consumers will build a trust and are encouraged to purchase through online shopping. Besides, the lack of direct experience with the product within e-commerce, leads to a feeling of uncertainty and therefore constitutes a risk for the consumers when buying online. This perceived risk results in a growing number of order returns, uncompleted order processes and consumers without any online purchase intention (Yaoyuneyong et al. 2014).

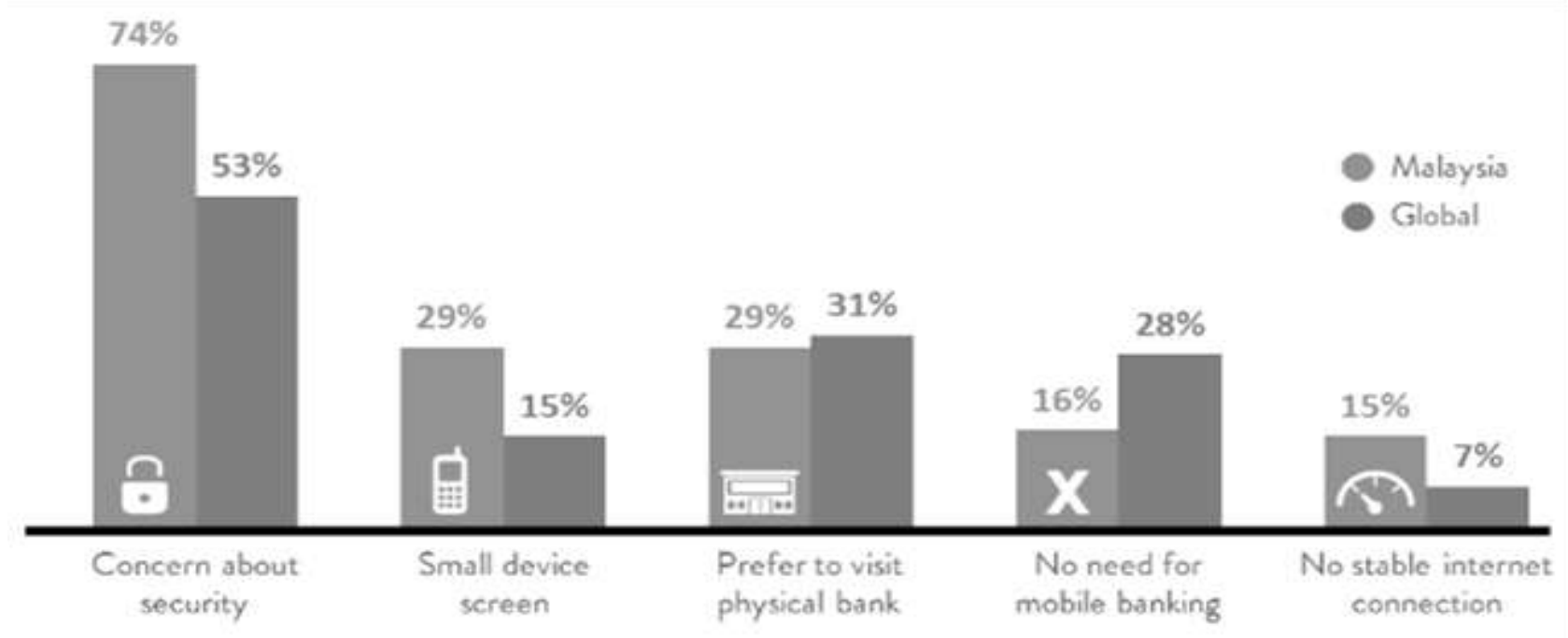

Figure 2: Reason why Malaysians are not likely to using online purchasing Source: Nielson Global Survey, 2016

Trust is the second factor that influence consumer attitude. A lack of trust and negative attitude toward websites and brands have been identified as critical factors that impact purchase intention in an online context (Wu, Quyen \& Rivas, 2017). According to Kim (2012), consumers' trust in their pre-purchase decision may positively affect the consumers' intention to purchase. Chiu, Huang and Yen (2010) proved in their study that trust is a positive predictor of consumer intention to purchase and can reduce the insecurity especially buying through online (Shiau and Chau, 2013). Based on previous studies, the lack of trust generates a negative effect on the willingness to 
INTERNATIONAL JOURNAL OF ACADEMIC RESEARCH IN BUSINESS AND SOCIAL SCIENCES Vol. 10, No. 6, June, 2020, E-ISSN: 2222-6990 @ 2020 HRMARS

participate in online purchasing activities (Meskaran et al, 2013) and reasons why consumers do not engage in e-commerce (Lee and Turban, 2001). It is proven by MCMC (2017), where the report shows that there are only $48.8 \%$ who does online shopping (refer figure 3 ). Although online advertising has become a trend nowadays, some people experience a lack of trust towards online transaction. There is a need to investigate this issue as well, because without a clear understanding of consumer behavior, it would be difficult to devise effective marketing and sales strategies and even business models (Nejati et al. 2011). Hew (2017) revealed that most Malaysians do not trust the information from the internet, and only $17 \%$ of consumers trust the information from internet especially social media.

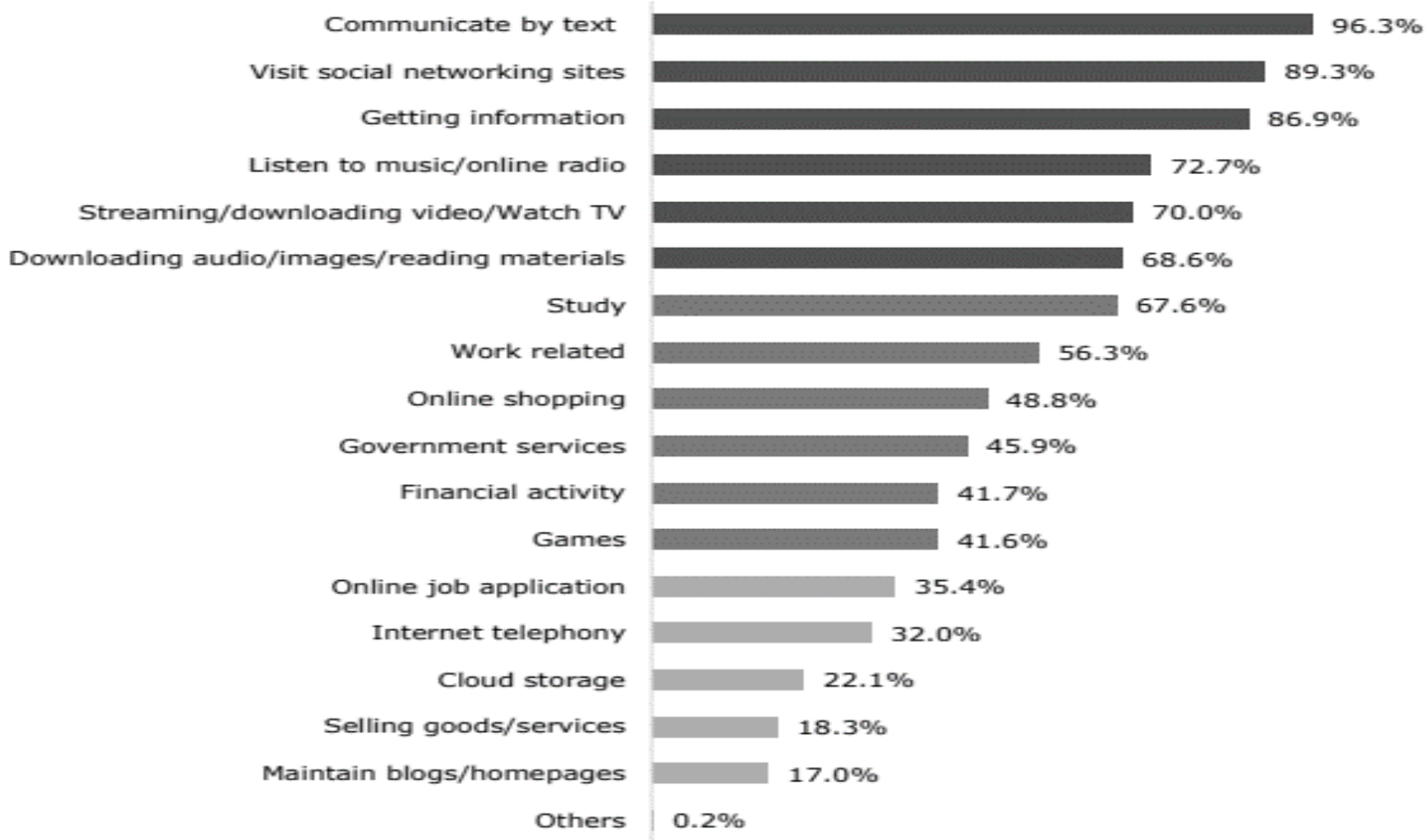

Figure 3 : Percentage of internet users by online activities Source: Malaysian Communications and Multimedia Commission (MCMC) 2017

The third factor is web design. Retail stores have evolved from a simple sales outlet to an 'interactive theatre' or 'experience stager'. The concept of 'store atmospherics' has received attention not only from researchers but also from vendors in both offline and online modes. Hasan (2016) found that websites with an unpleasant visual design elicited feeling of irritation with users and upset them. A study done by Jin et al. 2015 suggested that website design to be explained in online shopping activities. Although a considerable amount of literature has been gathered on the impact of store atmospherics in traditional retail, there is a dearth of research studies in the online context (Bedi, Kaur \& Lai, 2017). Various academic studies (Brady \& Phillips, 2003; Ganguly et al. 2010) have confirmed that attractiveness significantly affects the usability of a website. A study in the Indian context by Ganguly, Dash and Cyr (2009) related to website characteristics has taken into consideration some of the variables related to online website but they have not directly measured the online website construct. Eroglu, Machleit and Davis (2003) were the first to measure the impact 
of site website on shopping outcome. They have clearly suggested that website design affect the level of pleasure felt, which in turn leads to attitude formation and then online purchase intention. The findings of Eroglu et al. (2003) study posited that web design affects attitude towards online shopping intention. Cyr (2008) empirically proved that visual design of a website affects attitude and purchase intention. In an online environment, a website is the point of contact between the consumer and the firm, so online vendors need to build effective websites to enhance and maintain customer relationships (Wu, Quyen \& Rivas, 2017). Therefore, its visual design has a great influence on the purchase intention of a consumer (Bramall, Schoefer \& Mckechnie, 2004).

Lastly, perceived ease of use is also considered as a factor that influences consumer attitude. It is the perception of an individual that it requires no cost or effort in the adoption of new system or technology. Supporting the importance of ease of use for the retailers, research suggests that ease of use is one of the factors that initiate customers to act with repeat purchases (Gefen, Karahanna, \& Straub, 2003). Malaysia is at the early stage of the era of internet marketing, thus prefer ease of use as an important factor to influence them to purchase online (Isa and Wong, 2015). A good website for a retailer should support easy navigation and customer intuition (Yang, Jun, \& Peterson, 2004). Hence, the information and content should be concise and easy to understand. The information and content provided on the website should encourage customers to be self-reliant throughout the whole transaction. Any difficulties or incomprehensible situations the customer encounters will create frustration and incompetence for the customer, making them less satisfied (Yang et al. 2004). The interacting design is crucial for the prerequisite of the customer being independent throughout the transaction, and it requires comprehensive design and production. According to Rose et al. (2012), the ease of use is an important factor in the online environment. The research addresses that ease of use affects the likelihood of repeated purchases, making it an important experiential factor for consumer attitude.

\section{Conclusion}

There is abundant literature that discussed online shopping, and this study gives an overview on the barriers and obstacles faced by Malaysian e-commerce. It provides guidelines for the e-commerce vendors, businesses and stakeholders to guide their efforts to encounter the barriers. However, this study is still at early stage and needed further validation by reputable scholars and experts in the field to enhance its credibility. Thus, the issue will be explored further through quantitative study.

\section{Acknowledgement}

The researcher would like to thank the Faculty of Technology Management and Technopreneurship (FPTT), Universiti Teknikal Malaysia Melaka and Universiti Teknologi MARA Melaka for the opportunity given in order to run this study.

\section{Corresponding Author}

Roszi Naszariah Nasni Naseri; Faculty of Technology Management \& Technopreneurship, Universiti Teknikal Malaysia Melaka and Universiti Teknologi MARA Melaka, Malaysia

Email: roszinaseri@gmail.com

\section{References}

Azeem, M. A. (2012). Consumers' Attitudes toward Commercial E-mail Spam and Web pop-ups: Interference, Perceived Loss of Control, and Irritation. Inf. Knowl. Manag. 2, 21-33. 
INTERNATIONAL JOURNAL OF ACADEMIC RESEARCH IN BUSINESS AND SOCIAL SCIENCES

Vol. 10, No. 6, June, 2020, E-ISSN: 2222-6990 @ 2020 HRMARS

Bart, Y., Shankar, V., Sultan, F., \& Urban, G. L. (2005). Are the drivers and role of online trust the same for all web sites and consumers? A large-scale exploratory empirical study. Journal of marketing, 69(4), 133-152.

Bedi, S. S., Kaur, S., \& Lal, A. K. (2017). Understanding web experience and perceived web enjoyment as antecedents of online purchase intention. Global Business Review, 18(2), 465-477.

Belkhamza, Z., \& Niasin, M. A. F. (2017). The Effect of Privacy Concerns on Smartphone App Purchase in Malaysia: Extending the Theory of Planned Behavior. International Journal of Interactive Mobile Technologies (iJIM), 11(5), 178-194.

Bhatt, A. (2014). Consumer attitude towards online shopping in selected regions of Gujarat. Journal of Marketing Management, 2(2), 29-56.

Brady, L., \& Phillips, C. (2003). Aesthetics and usability: A look at color and balance. Usability News, 5(1), 2-5.

Bramall, C., Schoefer, K., \& McKechnie, S. (2004). The determinants and consequences of consumer trust in online environments: an exploratory investigation. International Journal of Internet Marketing and Advertising, 1(4), 388-412.

Chiu, C. M., Huang, H. Y., \& Yen, C. H. (2010). Antecedents of trust in online auctions. Electronic Commerce Research and Applications, 9(2), 148-159.

Cyr, D. (2008). Modeling web site design across cultures: relationships to trust, satisfaction, and eloyalty. Journal of Management Information Systems, 24(4), 47-72.

Florian, E. N. (2000). Towards a Model of Trust for E-Commerce System Design. In Proc. of the CHI2000 Workshop: Designing Interactive Systems for (pp. 38-43).

Eroglu, S. A., Machleit, K. A., \& Davis, L. M. (2003). Empirical testing of a model of online store atmospherics and shopper responses. Psychology \& marketing, 20(2), 139-150.

Faqih, K. M. S. (2016). An empirical analysis of factors predicting the behavioural intention to adopt internet shopping technology among non-shoppers in a developing country context: does gender matter. Journal of Retailing and Consumer Services, 30, 140-164.

Ganguly, B., Dash, S. B., \& Cyr, D. (2009). Website characteristics, Trust and purchase intention in online stores: -An Empirical study in the Indian context. Journal of Information Science \& Technology, 6(2).

Ganguly, B., Dash, S. B., Cyr, D., \& Head, M. (2010). The effects of website design on purchase intention in online shopping: the mediating role of trust and the moderating role of culture. International Journal of Electronic Business, 8(4-5), 302-330.

Gefen, D., Karahanna, E., \& Straub, D. W. (2003). Trust and TAM in online shopping: An integrated model. MIS quarterly, 27(1), 51-90.

Haque, A., Khatibi, A., \& Mahmud, S. A. (2009). Factors determinate customer shopping behaviour through internet: The Malaysian case. Australian Journal of Basic and Applied Sciences, 3(4), 3452-3463.

Haque, A., Sadegzadeh, J., Khatibi, A., \& Al Mahmud, S. (2006). Investigating potentially affective factors of online sales: a study on Malaysian business online. International Journal of Information Systems and Change Management, 1(4), 374-395.

Harn, A. C. P., Khatibi, A., \& Ismail, H. B. (2006). E-Commerce: A study on online shopping in Malaysia. Journal of Social Sciences, 13(3), 231-242.

Hasan, B. (2016). Components of Online Shopping Attitude and the Effects of Website Design Characteristics. Journal of Information \& Knowledge Management, 15(03), 1650028. doi:10.1142/s0219649216500283 
INTERNATIONAL JOURNAL OF ACADEMIC RESEARCH IN BUSINESS AND SOCIAL SCIENCES

Vol. 10, No. 6, June, 2020, E-ISSN: 2222-6990 @ 2020 HRMARS

Hew, J. J. (2017). Hall of fame for mobile commerce and its applications: A bibliometric evaluation of a decade and a half (2000-2015). Telematics and Informatics, 34(1), 43-66.

Isa, S. M., \& Wong, K. Y. (2015). Age differences in behavioral intention to use internet marketing: A comparative study between Malaysian and Taiwanese. International Journal of Business and Society, 16(3).

Jamil, N. A., \& Mat, N. K. (2011). To Investigate the Drivers of Online Purchasing Behavioural in Malaysia Based on the Theory of Planned Behavior (TPB): A Structural Equation Modelling (SEM) Approach. International Conference on Management, (pp. 453-460).

Jin, L. Y., Osman, A., Romle, A. R., \& Haji-Othman, Y. (2015). Attitude towards online shopping activities in Malaysia public university. Mediterranean Journal of Social Sciences, 6(2 S1), 456.

Kim, J. B. (2012). An empirical study on consumer first purchase intention in online shopping: integrating initial trust and TAM. Electronic Commerce Research, 12(2), 125-150.

Kudeshia, C., \& Kumar, A. (2017). Social eWOM: does it affect the brand attitude and purchase intention of brands. Management Research Review.

Lee, M. K., \& Turban, E. (2001). A trust model for consumer internet shopping. International Journal of electronic commerce, 6(1), 75-91.

Levy, M., and Weitz, B. A. (2016)., Retailing Management, McGraw-Hill, Irwin, CA.

Lim, Y. J., Osman, A., Salahuddin, S. N., Romle, A. R., \& Abdullah, S. (2016). Factors influencing online shopping behavior: the mediating role of purchase intention. Procedia economics and finance, 35(5), 401-410.

MCMC. (2017). Internet Users Survey 2017: Statistical Brief Number Twenty-One. Malaysian Communication and Multimedia Commission. ISBN 1823-2523

Meskaran, F., Ismail, Z., \& Shanmugam, B. (2013). Online purchase intention: Effects of trust and security perception. Australian journal of basic and applied sciences, 7(6), 307-315.

Muniady, R., Al-Mamun, A., Permarupan, P. Y., \& Zainol, N. R. B. (2014). Factors influencing consumer behavior: A study among university students in Malaysia. Asian Social Science, 10(9), 18.

Nejati, M., Shafaei, A., Salamzadeh, Y., \& Daraei, M. (2011). Corporate social responsibility and universities: A study of top 10 world universities' websites. African Journal of Business Management, 5(2), 440-447.

Nielson Global Survey. (2016). Mobile ecology: are Malaysian consumers ready for the new frontier of mobile banking and payment? Retrieved on 28 September 2018. Available at https://www.nielsen.com/my/en/insights/news/2016/are-malaysian-consumers-embracingthe-virtual-wallet.html

Oh, J. S., \& Jeong, D. Y. (2015). The effects of consumers' beliefs about TV home shopping advertising on attitude and purchase intention. Indian Journal of Science and Technology, 8(14), 1.

Park, H. H., Jeon, J. O., \& Sullivan, P. (2015). How does visual merchandising in fashion retail stores affect consumers' brand attitude and purchase intention. The International Review of Retail, Distribution and Consumer Research, 25(1), 87-104.

Punyatoya, P. (2015). Effect of perceived brand environment-friendliness on Indian consumer attitude and purchase intention. Marketing Intelligence \& Planning.

Ranganathan, C., \& Ganapathy, S. (2002). Key dimensions of business-to-consumer web sites. Information \& Management, 39(6), 457-465.

Rose, S., Clark, M., Samouel, P., \& Hair, N. (2012). Online customer experience in e-retailing: an empirical model of antecedents and outcomes. Journal of retailing, 88(2), 308-322. 
INTERNATIONAL JOURNAL OF ACADEMIC RESEARCH IN BUSINESS AND SOCIAL SCIENCES

Vol. 10, No. 6, June, 2020, E-ISSN: 2222-6990 @ 2020 HRMARS

Salem ur Rahman. (2018). Motivations and barriers to purchasing online: understanding consumer responses. South Asian Journal of Business Studies, 7(1), 111-128.

Shiau, W.-L., \& Chau, P. (2013). Does Altruism Matter on Online Group Buying? Perspectives from Egotistic and Altruistic Behavior. PACIS 2013 Proceedings, (p. 229).

The Malaysian Insider. (2011). Available on www.malaysianinsider.com

Tong, X. (2010). A Cross-National Investigation of an Extended Technology Acceptance Model in the Online Shopping Context. IJRDM, 30(10), 742-759.

$\mathrm{Wu}$, S. I. (2003). The relationship between consumer characteristics and attitude toward online shopping. Marketing intelligence \& planning .

Wu, W. Y., Quyen, P. T. P., \& Rivas, A. A. A. (2017). How e-servicescapes affect customer online shopping intention: the moderating effects of gender and online purchasing experience. Information Systems and e-Business Management, 15(3), 689-715.

Wulandari, A. A., Rahyuda, I. K., \& Yasa, N. N. K. (2015). The role of attitude in mediating consumer knowledge influence towards the purchase intention of green product. Jurnal Dinamika Manajemen, 6(2), 1-10.

Yaoyuneyong, G., Foster, J. K., \& Flynn, L. R. (2014). Factors impacting the efficacy of augmented reality virtual dressing room technology as a tool for online visual merchandising. Journal of Global Fashion Marketing, 5(4), 283-296.

Yeo, V. C. S., Goh, S. K., \& Rezaei, S. (2017). Consuer experiences, attitude and behavioral intention toward online food delivery (OFD) services. Journal of Retailing and Consumer Services, 35, 150162.Zendehdel, M., Paim, L., Bojei, J., \& Osman, S. (2011). The effects of trust on online Malaysian students buying behavior. Australian Journal of Basic and Applied Sciences, 5(12), 1125-1132. 